\title{
POJĘCIE SZKODY I ODPOWIEDZIALNOŚCI PRAWNEJ JAKO PODSTAWA KSZTAETOWANIA PRODUKTU UBEZPIECZENIA ŚRODOWISKOWEGO
}

\author{
LEGAL TERMS OF DAMAGE AND LIABILITY \\ AS THE BASIS FOR THE CREATION \\ OF ENVIRONMENTAL INSURANCE PRODUCTS
}

http://dx.doi.org/10.12775/PPOS.2016.010

\section{STRESZCZENIE}

Pojęcie szkody i odpowiedzialności prawnej w obszarze oddziaływania na elementy środowiska naturalnego determinują zakres możliwej kompensacji realizowanej poprzez produkty ubezpieczeniowe. Ustawowy wykaz grup ubezpieczeń, a także gospodarcza natura kontraktu ubezpieczenia, która warunkuje ubezpieczalność ryzyka stanowią podstawę zawężenia możliwej kompensacji poprzez system ubezpieczeń własnych (first party). Granice odpowiedzialności praw-

* Doktor nauk ekonomicznych, Uniwersytet Ekonomiczny w Poznaniu. 
nej za popełnione czyny są z kolei podstawą ograniczenia zakresu akcesoryjnej odpowiedzialności ubezpieczyciela w ubezpieczeniach odpowiedzialności (third party).

\section{Słowa kluczowe}

Szkoda środowiskowa; odpowiedzialność środowiskowa; ubezpieczenia środowiskowe.

\section{ABSTRACT}

The provisions of the Civil Code and environmental law on liability for harm to the environment determine a range of insurance cover and, therefore, are sufficient basis for the creation of liability insurance products (third party insurance). However, it is not enough for other types of environmental insurance. The factors of freedom to contract and insurance law barriers also need to be considered when creating further insurance products (first party insurance). The scope of these products and their attributes are nowadays difficult to predict, because of still changing legal and economic factors, that determine demand and supply on the insurance market.

\section{Keywords}

Environmental damage; environmental liability; environmental insurance.

\section{WPROWADZENIE}

Wielość produktów ubezpieczeniowych i zróżnicowanie treściowe klauzul w przedmiocie odpowiedzialności ubezpieczyciela za szkody środowiskowe tworzy nieprzejrzysty i pełen luk obraz ochrony ubezpieczeniowej w tym obszarze. W artykule podjęta zostanie próba wskazania roli prawnego ujęcia szkody środowiskowej jako determinanty kształtowania produktów ubezpieczeń środowiskowych. W pierwszej kolejności przeprowadzona zostanie krytyczna analiza literatury przedmiotu i praktyki gospodarczej w zakresie wieloznaczności pojęcia 
ubezpieczeń środowiskowych. Następnie wyjaśnione zostanie w jakim zakresie prawne ujęcie szkody środowiskowej może/powinno determinować zakres ochrony $\mathrm{w}$ produktach ubezpieczeń środowiskowych.

\section{ZAKRES POJĘCIA UBEZPIECZEŃ ŚRODOWISKOWYCH - PRZEGLĄD LITERATURY}

Pojęciowe wyodrębnienie kategorii ubezpieczeń środowiskowych nastręcza wiele problemów. Analiza polskojęzycznej literatury przedmiotu pozwala wyodrębnić przynajmniej trzy interpretacje tego zagadnienia. Pierwsze z nich - ujęcie szerokie - nie pozwala na stosowanie terminu „ubezpieczenia środowiskowe" wobec jakiegokolwiek wyodrębnionego zbioru produktów ubezpieczenia. Podejście to jest konsekwencją przyjętej koncepcji ryzyka środowiskowego, którego źródła dopatruje się we wszelkich interakcjach zachodzących między przedsiębiorstwem i środowiskiem ( $w$ tym również w oddziaływaniu sił przyrody niezwiązanych z zanieczyszczeniem - np. huraganów, gradobicia - na przedsiębiorstwo). Wobec powyższego, elementów ochrony przed skutkami realizacji ryzyka środowiskowego można doszukiwać się w konstrukcji niemalże wszystkich dostępnych na rynku ubezpieczeniowym produktów ${ }^{1}$. Wydaje się to sprzeczne po pierwsze, z praktyką gospodarczą (stosowanie pojęcia ubezpieczeń środowiskowych w ujęciu wąskim), po drugie z ideą podziału produktów (czy ich komponentów) na jednorodne grupy, co ma umożliwić precyzyjne określanie przedmiotu badań (ujęcie naukowe) oraz rozwój i zarządzanie produktami ubezpieczeniowymi (ujęcie gospodarcze). Podejście umiarkowane do definiowania pojęcia ubezpieczeń środowiskowych

1 Por. A. Doś, Ryzyko ekologiczne przedsiębiorstw na rynku ubezpieczeń majątkowych, Warszawa 2011, s. 17, 81; nieco węższe ujęcie: G. Borys, Ryzyko ekologiczne i jego systematyka na gruncie teorii ubezpieczeniowej, [w:] Instrumenty rynkowe $w$ ochronie środowiska, S. Czaja (red.), Jugowice-Wrocław 2002, s. 41. 
każe w ich obrębie wyróżnić ubezpieczenia odpowiedzialności za szkody w środowisku oraz ubezpieczenia rzeczowe chroniące mienie ubezpieczonego przed skutkami zanieczyszczenia ${ }^{2}$. Do grupy umiarkowanego podejścia zaliczyć należy koncepcję rozszerzenia wyżej wskazanego zakresu o ubezpieczenia osobowe wynikające $\mathrm{z}$ zanieczyszczeń ${ }^{3}$. Najwęższe ujęcie ubezpieczeń środowiskowych ogranicza je do ubezpieczeń odpowiedzialności za szkody ekologiczne ${ }^{4}$ i jest ono zgodne z obecną praktyką gospodarczą w Polsce.

Konkretyzowanie zagadnienia w literaturze zagranicznej ogranicza się w zdecydowanej większości do wskazania ubezpieczeń odpowiedzialności prawnej. Dominujące podejście zastrzega stosowalność terminu „ubezpieczenie środowiskowe” do produktu ubezpieczenia, który chroni podmiot ryzyka przed roszczeniami zgłaszanymi przeciwko niemu z tytułu zanieczyszczenia środowiska, przy czym roszczenia te wynikają z powstania odpowiedzialności, która jest jednak odmiennie definiowana w różnych systemach prawnych. Może to być odpowiedzialność generowana ex lege (ang. statutory liability) jak również po-

2 Por. D. Maśniak, Ubezpieczenia ekologiczne, Kraków 2003, s. 140; K. Rosiek, Zakres pojęcia „szkoda ekologiczna” w ubezpieczeniach ekologicznych, „Zeszyty Naukowe Akademii Ekonomicznej w Krakowie” 2006, Nr 708, s. 102-103; T. Żebrowska, Ubezpieczenia ekologiczne a ochrona środowiska naturalnego, „Wiadomości Ubezpieczeniowe” 1997, Nr 3-4, s. 11. Należy zauważyć, że wskazane źródła wyróżniają jedynie odpowiedzialność cywilną, abstrahują z kolei od odpowiedzialności administracyjnej. Wynika to z faktu, że wszystkie są datowane przed rokiem 2007, w którym została uchwalona ustawa z dnia 13 kwietnia 2007 r. o zapobieganiu szkodom w środowisku i ich naprawie, tekst jedn. Dz.U. z 2014 r. poz. 1789 ze zm. (dalej cyt.: ustawa szkodowa; u.sz.) ustanawiająca odpowiedzialność administracyjną za szkody środowiskowe.

3 Por. P. Wójcik, Ubezpieczenia odpowiedzialności za szkody w środowisku, „Prawo, Ubezpieczenia, Reasekuracja” 1998, Nr 5, s. 45-46; A. Panasiewicz, Ubezpieczenia środowiskowe jako czynnik przyspieszenia przemian prośrodowiskowych, [w:] Ubezpieczenia wobec wyzwań XXI wieku, W. Ronka-Chmielowiec (red.), „Prace Naukowe Akademii Ekonomicznej we Wrocławiu” 2008, Nr 1197, s. 322.

4 Por. B. Fiedor, Economic Aspects of Ecological Liability and its Insurance, International Experiences and the Polish Case, s. 16, http://web.sfc.keio. ac.jp/ kgw/Research/JPJRP/ResearchPaper2003/Fiedor.pdf, 10.09.2015. 
wstała na skutek decyzji uprawnionych organów (ang. regulatory liability). Ponadto wynika ona z negatywnego oddziaływania na elementy środowiska $\mathrm{w}$ ramach działalności podmiotu ryzyka (zasada „zanieczyszczający płaci”) bądź też z samego tytułu własności zanieczyszczonego terenu ${ }^{5}$. Względnie szerokie podejście prezentowane w literaturze zagranicznej, ujmuje w zakresie ubezpieczeń środowiskowych kategorię ubezpieczeń finansowych. Gwarantują one ochronę w przypadku niespłacenia kredytów zabezpieczonych hipoteką na nieruchomościach, na których zidentyfikowane zostanie - w czasie jej trwania - zanieczyszczenie podlegające rekultywacji lub remediacji, do której zobowiązany jest władający powierzchnią ziemi ${ }^{6}$.

Przegląd literatury przedmiotu uzupełnić należy o koncepcje przyjmowane przez organizacje międzynarodowe. Względnie szerokie podejście prezentuje w swoim Programie Środowiskowym Organizacja Narodów Zjednoczonych (United Nations Environment Programme - UNEP). Do ubezpieczeń środowiskowych zalicza te produkty, które są powiązane $\mathrm{z}$ określonym obszarem potencjalnie zanieczyszczonym - w zakresie kosztów działań naprawczych, a także ubezpieczenia odpowiedzialności wobec osób trzecich wynikłej z zanieczyszczeń, czy produkty powiązane $\mathrm{z}$ transportem substancji niebezpiecznych. Ubezpieczeniami środowiskowymi są według koncepcji UNEP również niektóre ubezpieczenia finansowe gwarantujące ochronę w zakresie kosztów ponoszonych przy okazji zamknięcia lub po zamknięciu określonej - niebezpiecznej dla środowiska działalności, a także produkty chroniące przed kosztami prze-

5 Por. np. Firms may face environmental black hole, „Reactions” May 2013, s. 52; . D.M. Minoli, J.N.B. Bell, Composite insurer consideration and attitudes on environmental management systems concerning public liability policies for pollution risks, "Journal of Environmental Assessment Policy and Management" 2002, vol. 4, no. 3, s. 331; C.J. Forrest, D.L. Wesley, The Environmental Manager's Guide to Environmental Liability Insurance, "Environmental Quality Management" Spring 2008, s. 2; M. Boyer, D. Porrini, The Efficient Liability Sharing Factor for Environmental Disasters: Lessons for Optimal Insurance Regulation, "The Geneva Papers" 2008, no. 33, s. 340.

6 Por. J.W. Broderick, D.R. Lavoie, A.J. Perel, Environmental Risk Management and the Role of Environmental Insurance, "Environmental Quality Management", Autumn 2000, s. 5-8. 
wyższającymi założenia projektowe w zakresie rekultywacji, czy też ubezpieczenia usługodawców (w tym konsultantów środowiskowych) od odpowiedzialności wobec osób trzecich za powstałe szkody środowiskowe ${ }^{7}$. Rozległość zaprezentowanego ujęcia ma jedynie wymiar produktowy, przedmiotowo wszystkie wskazane produkty mają charakter ubezpieczeń odpowiedzialności za szkody środowiskowe.

Konstrukcję ubezpieczeń środowiskowych opartą na różnie prawnie definiowanej odpowiedzialności przyjmuje również OECD. Choć przyjęta w opracowaniu definicja ryzyka środowiskowego pozostaje szeroka (ryzyko środowiskowe jest generowane przez wszelkie interakcje podmiotu ryzyka ze środowiskiem) to termin ubezpieczeń środowiskowych (niezdefiniowany wprost) używany jest jedynie w kontekście ubezpieczeń szeroko rozumianej odpowiedzialności za szkody środowisko$w^{8}$. Katastrofy naturalne - będące źródłem realizacji ryzyka środowiskowego - są objęte ochroną przez ubezpieczenia katastroficzne, przede wszystkim o charakterze rzeczowym. Istotnie zawężające podejście do ubezpieczeń prezentują dokumenty Komisji Europejskiej, które pojęcie „rynek ubezpieczeń środowiskowych" odnoszą wyłącznie do ubezpieczeń odpowiedzialności wynikającej z regulacji dyrektywy szkodowej'

7 Zob. Risk, The Environment and The Role of The Insurance Industry, UNEP Finance Initiatives, February 2003, s. 16-17.

8 Zob. Environmental Risks and Insurance, A Comparative Analysis of The Role of Insurance in The Management of Environment-Related Risks, "Policy Issues in Insurance" 2003, no. 6, OECD, s. 21-53.

9 Dyrektywa 2004/35/WE Parlamentu Europejskiego i Rady z 21 kwietnia 2004 r. w sprawie odpowiedzialności za środowisko w odniesieniu do zapobiegania i zaradzania szkodom wyrządzonym środowisku naturalnemu, Dz.Urz. UE L 143 z 2004 r., s. 56 ze zm., dalej cyt.: dyrektywa szkodowa; Study on implementation effectiveness of the environmental liability directive (ELD) and related financial security issues, European Commission, Bio Intelligence Service in association with Stevens\&Bolton LLP, November 2009, s. 52 i nast. 


\subsection{EWOLUCJA NORM PRAWNYCH W ODNIESIENIU DO ODPOWIEDZIALNOŚCI ŚRODOWISKOWEJ JAKO HISTORYCZNA DETERMINANTA ZAKRESU POJĘCIA UBEZPIECZENIE ŚRODOWISKOWE}

Powyżej zarysowany problem chaosu pojęciowego jest w dużej mierze efektem ewolucji uwzględniania w praktyce rynków ubezpieczeniowych zagrożenia ryzykiem środowiskowym. Stopień istotności przypisywany temu zagrożeniu wynika nie tylko z charakterystyk zdarzeń prowadzących do realizacji ryzyka i zasięgu ich konsekwencji, ale nadto z wielości i zmienności regulacji określających odpowiedzialność podmiotów oddziałujących na środowisko ${ }^{10}$. Do wczesnych lat siedemdziesiątych (USA) i około 10 lat dłużej w Europie ryzyko odpowiedzialności za szkody środowiskowe uwzględniane było bez istotnych wyłączeń w ubezpieczeniach odpowiedzialności cywilnej. Podobnie ubezpieczenia rzeczowe nie wyłączały szkód wynikłych z zanieczyszczeń. Rozpoczęta w 1972 roku $^{11}$ i trwająca po dziś aktywność regulacyjna w zakresie szkód środowiskowych, a także coraz liczniejsze zobowiązania ubezpieczycieli z tytułu odpowiedzialności ubezpieczonych podmiotów za szkody środowiskowe zrodziła tendencję do ograniczania zakresu ubezpieczeń, początkowo w odniesieniu do zdarzeń stopniowo zanieczyszczających (szkody kumulacyjnej), potem również pozostałych związanych $\mathrm{z}$ negatywnym oddziaływaniem podmiotów na środowisko. Ze względu na brak doświadczenia w zakresie underwritingu i kwotowania ryzyka środowiskowego rynek ubezpieczeń środowiskowych topniał a przedsiębiorstwa doświadczały licznych luk pokrycia ochroną ubezpieczeniową swoich interesów majątkowych. Stan ten stworzył korzystne uwarunkowania do rozwoju wyspecjalizowanych produktów, które wraz

10 Ocenia się, że w skali światowej jest ponad 17000 regulacji prawnych poruszających kwestię oddziaływania podmiotów na środowisko. Zob. M.R. Szot, P.D. Maxwell, Environmental insurance gaps in coverage, "Smart Bisuness Detroit", June 2011, s. 18.

11 Rok uchwalenia The Clean Water Act w USA, zob.: C.J. Forrest, D.L. Wesley, op.cit., s. 2. 
z rosnącym doświadczeniem ubezpieczycieli oraz coraz większą stabilnością regulacji prawnych, zyskują i będą dalej zyskiwały na znaczeniu ${ }^{12}$. Co więcej, regulacje prawne stopniowo ugruntowują zasadę „zanieczyszczający płaci” na poszczególnych obszarach negatywnego oddziaływania podmiotów ryzyka na środowisko ${ }^{13}$, a nadto zaostrzają stopniowo odpowiedzialność, przechodząc od odpowiedzialności opartej na zasadzie winy do tej opartej o zasadę ryzyka. Jednocześnie często wskazują na konieczność zapewnienia zabezpieczenia finansowego na wypadek realizacji ryzyka środowiskowego ${ }^{14}$.

Kwestia zabezpieczenia finansowego była po wielokroć przedmiotem prac legislacyjnych. Już konwencja z Lugano ${ }^{15}$ w art. 13-16, choć nie wprowadza jednolitych obowiązkowych zabezpieczeń finansowych, to jednak obliguje strony konwencji do zapewnienia - tam gdzie jest to konieczne - uczestnictwa podmiotów w systemach gwarancyjnych, czy też nabywania przez nie odpowiednich finansowych instrumentów ochronnych $^{16}$. Na gruncie legislacyjnej aktywności instytucji europejskich powstał projekt dyrektywy dotyczącej odpowiedzialności cywilnej podmiotów za szkody spowodowane gospodarką odpadami ${ }^{17}$, wprowadzający odpowiedzialność na zasadzie ryzyka, wymóg posiadania zabezpieczeń finansowych oraz zasadę

12 Uważa się, że pierwsze specjalistyczne ubezpieczenia środowiskowego zostały zaoferowane przez Lloyd's of London w 1979 r., por. Risk, The Environment..., op.cit., s. 16 .

13 Regulacje te stanowione były zarówno na płaszczyźnie krajowej (np. w USA m.in. Clean Water Act, Clean Air Act, Resource Conservation and Recovery Act - RCRA, Comprehensive Environmental Response, Compensation and Liability Act - CERCLA) oraz międzynarodowej: liczne konwencje dotyczące zanieczyszczenia olejami, energii jądrowej, transportu substancji niebezpiecznych, niebezpiecznych odpadów. Por. Międzynarodowe prawo środowiska, wyb. i wprow. M.M. Kenig-Witkowska, Warszawa-Kraków 2009, s. 44.

14 Por. M.M. Kenig-Witkowska, op.cit., s. 45.

15 Convention on Civil Liability for Damage Resulting from Activities Dangerous to the Environment. Lugano, 21 June 1993.

16 Pr. M. Hinteregger, Environmental Liability and Ecological Damage in European Law, Cambridge University Press 2008, s. 4.

17 Proposal for a Council Directive on Civil Liability for Damage caused by Waste, COM(89)282; Proposal for a Council Directive on the Landfill of Waste, $\operatorname{COM}(93) 275$. 
actio directa ${ }^{18}$. Choć dyrektywa ta nie weszła w życie, to jednak uaktywniła legislacyjne zainteresowanie problematyką szkód środowiskowych. W 1992 r. opublikowano Zieloną Księgę dotyczącą odpowiedzialności za szkody środowiskowe, następnie Białą Księgę odnoszącą się do odpowiedzialności środowiskowej (2000 r.), która stała się podstawą uchwalenia w 2004 r. dyrektywy szkodowej. Zabezpieczenie finansowe zostało wskazane jako pożądane, ale nie obligatoryjne (art.14). Komisja jednak zastrzega sobie dyrektywalnie prawo do wprowadzenia systemu zabezpieczenia obowiązkowego, jeśli będzie to konieczne ${ }^{19}$.

\subsection{UBEZPIECZENIA ŚRODOWISKOWE - PROPOZYCJA KONKRETYZACJI POJĘCIA}

Mając na względzie aktualny stan prawny, w tym w szczególności zasadę zanieczyszczający płaci, ewolucję ram prawnych konkretyzujących pojęcie szkody środowiskowej i odpowiedzialności za nią, praktyki rynkowe, a także ustawową i doktrynalną definicję ubezpieczenia można uznać, że ubezpieczenia środowiskowe to instrument gospodarczy, w którym ubezpieczyciel zobowiązuje się do wypłaty określonego świadczenia w razie zajścia jednego lub więcej z następujących zdarzeń:

1) powstania odpowiedzialności (cywilnej lub administracyjnej) z tytułu oddziaływania na środowisko (ubezpieczenia odpowiedzialności środowiskowej);

2) powstania uszczerbku w interesach majątkowych ubezpieczonego innych niż związanych z powstaniem odpo-

18 Por. A.B. Coulson, R. Dixon, Environmental Risk and management strategy: the implications for financial institutions, "International Journal of Bank Marketing" 1995, Vol. 13, No. 2, s. 23.

19 Raport Komisji w sprawie stopnia transpozycji dyrektywy do krajowych porządków prawnych z 2010 r., wskazywał na brak podstaw do utworzenia sytemu ubezpieczeń obowiązkowych na szczeblu unijnym, por. Sprawozdanie Komisji dla Rady, Parlamentu Europejskiego, Europejskiego Komitetu Ekonomiczno-Społecznego i Komitetu Regionów, na mocy art. 14 ust. 2 dyrektywy 2004/35/WE w sprawie odpowiedzialności za środowisko w odniesieniu do zapobiegania i zaradzania szkodom wyrządzonym środowisku naturalnemu, Bruksela, dnia 12.10.2010, KOM(2010) 581, s. 12. 
wiedzialności, spowodowanego zanieczyszczeniem lub inną przyczyną pogarszającą jakość środowiska;

3) naruszenia dóbr osobistych ubezpieczonego spowodowanego zanieczyszczeniem lub inną przyczyną pogarszającą jakość środowiska.

Kluczowym elementem tak rozumianych ubezpieczeń środowiskowych są te zawarte w punkcie pierwszym. Ich postulowana powszechność marginalizowałaby znaczenie ubezpieczeń wymienionych w punktach 2 i 3 . Znaczenie tych drugich pozostanie najbardziej istotne wtedy, gdy podmiotem negatywnie oddziałującym na środowisko jest sam ubezpieczony. W wielu pozostałych przypadkach ubezpieczycielowi będzie przysługiwało prawo regresu względem zanieczyszczającego.

Praktyka rynkowa pokazuje, że poza ubezpieczeniami odpowiedzialności prawnej nie wykształciły się specjalistyczne produkty ubezpieczenia środowiskowego, a i w tym zakresie oferta polskiego rynku jest uboga, a szkody środowiskowe są najczęściej obejmowane ochroną na mocy klauzul dodatkowych ubezpieczeń ogólnych w bardzo okrojonym zakresie. W ubezpieczeniach mienia i w ubezpieczeniach osobowych szkody środowiskowe znajdują się zwykle w obszarze wyłączeń odpowiedzialności ubezpieczyciela w ubezpieczeniach all risks i nie znajdują się w zakresie ryzyka nazwanego w innych rodzajach ubezpieczeń. Wobec powyższego trudno wyodrębnić z rynku produkty ubezpieczenia dedykowane ochronie przed realizacją ryzyka środowiskowego w zakresie pkt 2 i 3. Znamiona środowiskowe noszą bowiem zarówno produkty, które rezygnują z wyłączenia zagrożenia środowiskowego z katalogu przyczyn realizacji ryzyka, jednocześnie nie włączając go w kategorię ryzyka nazwanego (np. ubezpieczenia chorobowe, gdzie ubezpieczyciel nie identyfikuje przyczyn choroby), jak również te, które poprzez nazwanie ryzyka lub wyraźnie wyróżnioną klauzulę umożliwiają objęcie ochroną ryzyka środowiskowego.

Wydaje się słuszne zawężenie przedmiotowego desygnatu pojęcia ubezpieczeń środowiskowych tylko do drugiej wymienionej kategorii. Zidentyfikowanie przez ubezpieczyciela zagrożenia środowiskowego $\mathrm{w}$ procesie projektowania produktu 2/2016 ubezpieczenia determinuje wagę znamion tego zagrożenia w re- 
alizacji procesu underwritingu. Można zatem przyjąć, że kryterium zakresu underwritingu powinno być decydujące w przypisywaniu produktu do kategorii ubezpieczeń środowiskowych. Przy takim ujęciu trudny do przewidzenia jest przyszły zasięg tej kategorii. Oferta tak rozumianych ubezpieczeń środowiskowych w dniu dzisiejszym ogranicza się do nielicznych wyspecjalizowanych produktów ubezpieczenia odpowiedzialności prawnej, a także innych, które przewidują zainicjowanie ochrony w badanym zakresie na mocy stosownych klauzul. W toku rozwoju rynku należy się jednak spodziewać jej rozszerzenia m.in. o produkty ubezpieczeń business interruption, osobowych, innych finansowych (związanych np. z emisją papierów wartościowych powiązanych z realizacją ryzyka środowiskowego).

\section{SZKODA ŚRODOWISKOWA ${ }^{20}$ I ODPOWIEDZIALNOŚĆ ODSZKODOWAWCZA}

Szkodę środowiskową należy rozważać na dwóch poziomach: tzw. pierwotna szkoda środowiskowa - stanowiąca bezpośredni efekt negatywnego wpływu na środowisko, co powoduje uszczerbek w zasobach naturalnych (powietrze, woda, gleba itp.) oraz wtórna szkoda środowiskowa, której skutkiem poprzez powstanie szkody pierwotnej - jest uszczerbek w dobrach majątkowych czy osobistych konkretnych podmiotów. Odpowiedzialność za szkodę pierwotną regulowana jest poprzez dwa reżimy prawne: (1) system odpowiedzialności cywilnej

20 Pojęcie szkody środowiskowej (dosłowne tłumaczenie z stosowanego w literaturze obcej pojęcia environmental loss) autorka rozumie szeroko, jako wszystkie szkody powstające w związku z zaistnieniem szkody dotyczącej środowiska (tj. na gruncie prawa polskiego szkody w środowisku lub szkody wyrządzonej oddziaływaniem na środowisko), por. B. Rakoczy, Szkoda w środowisku a szkoda wyrządzona oddziaływaniem na środowisko, [w:] Wybrane problemy prawa ochrony środowiska, B. Rakoczy, M. Pchałek (red.), Warszawa 2010, s. 335. 
(art. 322-328 ustawy Prawo ochrony środowiska ${ }^{21}$ w związku z art. 144 i $222 \S 2$ k.c. - ochrona praw o charakterze rzeczowym, oraz z art. 415 i $435 \S 1$ k.c. - odpowiedzialność deliktowa ${ }^{22}$ ) oraz (2) system odpowiedzialności administracyjnej (art. 362 pkt 2 u.p.o.ś.; ustawa z dnia 13 kwietnia 2007 r. o zapobieganiu szkodom w środowisku i ich naprawie ${ }^{23}$ ).

Cywilnoprawne ujęcie odpowiedzialności za szkodę pierwotną uprawnia do dochodzenia roszczeń podmioty reprezentujące interes ogółu, tj. Skarb Państwa, jednostki samorządu terytorialnego, a także organizacje ekologiczne (w sytuacji funkcjonowania środowiska jako dobra wspólnego ${ }^{24}$ ) lub właściciela elementu środowiska. Roszczenia te obejmują naprawienie szkód spowodowanych oddziaływaniem na środowisko poprzez przywrócenie stanu środowiska zgodnego z prawem ${ }^{25}$ oraz podjęcie środków zapobiegawczych. Ustawa Prawo ochrony środowiska zakłada implicite, że szkody mogą powstać na skutek oddziaływania jakiegokolwiek podmiotu (osoba fizyczna, przedsiębiorca) na wszystkie elementy środowiska, a także ich wzajemne oddziaływanie i relacje między nimi. Tak rozumiana szkoda jest zawsze wynikiem działania bezprawnego ${ }^{26}$. Wyjątek od

21 Ustawa z dnia 27 kwietnia 2001 r. Prawo ochrony środowiska, tekst jedn. Dz.U. z 2016 r. poz. 672, dalej cyt.: u.p.o.ś.

22 K. Gruszecki, Prawo ochrony środowiska. Komentarz, Warszawa 2011, s. 659-660.

23 Tekst jedn. Dz.U. z 2014 r. poz. 1789 ze zm.

24 Angloamerykańska tzw. trust doctrine zakłada, że poszczególne elementy środowiska stanowiące dobro publiczne są zarządzane przez państwo dla pożytku publicznego. Ustanawianie zasad odpowiedzialności za ich uszkodzenie, czy też ograniczenie zdolności do spełniania ich funkcji ma na celu kompensację ogółu. Por. M. Hinteregger, op.cit., s. 9.

25 Przywrócenie stanu środowiska zgodnego z prawem jest według niektórych poglądów doktryny odnoszone jedynie do takich sytuacji faktycznych, w których przepisy prawa określają standardy jakie powinno spełniać środowisko, por. K. Gruszecki, op.cit., s. 660; wydaje się jednak, że pojęcie standardów należy interpretować szeroko i odnosić nie tylko do elementów środowiska, ale również do wszystkich podmiotowych interesów podlegających ochronie prawnej, które mogą być naruszone poprzez negatywne oddziaływanie na środowisko.

${ }^{26}$ Ustawa nie określa niestety kryterium oceny bezprawności. Przyjmuje się jednak, że w tego typu stosunkach jest nim przeciętna miara oddziały- 
zasady bezprawności stanowią postanowienia art. 325 u.p.o.ś. jedynie w zakresie szkody wyrządzonej (nie zagrażającej) ${ }^{27}$. Przepis ten ugruntowuje zasadę odpowiedzialności za szkody środowiskowe nawet jeżeli działalność będąca przyczyną powstania szkody jest prowadzona na podstawie decyzji i w jej granicach. Aktywność niebezpieczna dla środowiska nie zawsze jest zabroniona, niemniej powinna być - w myśl postulatu zrównoważonego rozwoju - obarczona ciężarem naprawiania szkód wyrządzonych jej prowadzeniem.

Cywilnoprawna odpowiedzialność za szkody środowiskowe opiera się, w myśl regulacji ogólnej, na zasadzie winy. Modyfikacja tego rozwiązania - zakładająca szersze zobowiązania odszkodowawcze dla podmiotów zagrażających i wyrządzających szkody - oznacza wprowadzenie zasady ryzyka dla zakładów o zwiększonym lub o dużym ryzyku (art. 324 u.p.o.ś.) oraz zakładów wprowadzanych w ruch za pomocą sił przyrody (art. $435 \S 1$ k.c. $)^{28}$.

Zasada ryzyka warunkuje w znacznej mierze również odpowiedzialność o charakterze administracyjnym za szkody w środowisku, powstającą na mocy ustawy szkodowej (u.sz.). Pojęcie szkody $\mathrm{w}$ środowisku zostało zdefiniowane $\mathrm{w}$ art. 6 pkt 11 przywołanego aktu. Zgodnie z przyjętą definicją ustawa ogranicza się jedynie do regulacji szkód, które realizują się $\mathrm{w}$ trzech istotnych elementach środowiska (tj. gatunkach

wań w stosunkach sąsiedzkich. Zob. więcej W. Radecki, Ustawa o zapobieganiu szkodom $w$ środowisku i ich naprawie. Komentarz, Warszawa 2007, s. 28.

27 Por. E.K. Czech, Rola art. 325 Prawa ochrony środowiska $w$ odpowiedzialności cywilnej $w$ ochronie środowiska, „Przegląd Prawa Ochrony Środowiska" 2010, Nr 2, s. 9; K. Gruszecki, op.cit., s. 632.

28 Por. K. Gruszecki, op.cit., s. 631; Przez zakład rozumie się jedną lub kilka instalacji wraz z terenem, do którego prowadzący instalacje posiada tytuł prawny, oraz znajdującymi się na nim urządzeniami, por. art. 3 pkt 48 u.p.o.ś.; zakład o zwiększonym ryzyku lub dużym ryzyku to zakład stwarzający zagrożenie wystąpienia poważnej awarii przemysłowej. Podstawę zakwalifikowania zakładów do wymienionej kategorii stanowi wydane na podstawie art. 248 u.p.o.ś. rozporządzenie Ministra Rozwoju z dnia 29 stycznia 2016 r. w sprawie rodzajów i ilości znajdujących się w zakładzie substancji niebezpiecznych, decydujących o zaliczeniu zakładu do zakładu o zwiększonym lub dużym ryzyku wystąpienia poważnej awarii przemysłowej, Dz.U. z 2016 r. poz. 138. 
i siedliskach chronionych, wodach i w powierzchni ziemi, każdorazowo jedynie w ustawowo określonym zakresie). Tak rozumianą szkodę może wyrządzić podmiot korzystający ze środowiska $^{29}$, tj. przedsiębiorca, przedsiębiorca zagraniczny, osoba prowadząca działalność wytwórczą $\mathrm{w}$ rolnictwie, jednostka organizacyjna niebędąca przedsiębiorcą i osoba fizyczna (ale tylko, gdy korzysta ze środowiska w zakresie, w którym wymagane jest zezwolenie). Na zasadzie ryzyka odpowiadają wyżej wymienione podmioty jeżeli ustawa zalicza ich działalność do kategorii działalności stwarzającej ryzyko szkody w środowisku (art. 3 u.sz.). Inna niż wyżej wskazana aktywność podmiotów korzystających ze środowiska generuje odpowiedzialność na zasadzie winy i tylko w zakresie szkód wyrządzonych gatunkom chronionym i chronionym siedliskom przyrodniczym ${ }^{30}$. Tak rozumiana odpowiedzialność administracyjna obejmuje konieczność podejmowania zarówno działań zapobiegawczych, represyjnych jak i naprawczych. Obowiązek sprawcy powstaje ex lege, bez konieczności zgłaszania roszczeń z nim związanych (art. 9 u.sz.). Dopiero niepodjęcie ustawowych działań generuje aktywność organu ochrony środowiska (regionalnego dyrektora ochrony środowiska) polegającą na nałożeniu w drodze decyzji administracyjnej - obowiązku przeprowadzenia przewidzianych w ustawie działań (art. 15 u.sz.) bądź na bezpośrednim przeprowadzeniu działań zapobiegawczych i naprawczych w sytuacji gdy sprawca jest niezidentyfikowany, nie można przeciwko niemu wszcząć postępowania egzekucyjnego lub też egzekucja okazała się bezskuteczna oraz w okolicznościach, w których - ze względu na zagrożenie dla zdrowia ludzi lub możliwość zaistnienia nieodwracalnych szkód w środowisku - konieczne jest niezwłoczne podjęcie tych działań (art. 16 u.sz.). Niezależnie od tego, kto faktycznie wykonał przewidziane w ustawie zadania, ich koszty ponosi podmiot korzystający

29 Art. 3 pkt 20 u.p.o.ś.

30 Tytułem uzupełnienia należy dodać, że w szczególnych przypadkach obok podmiotu korzystającego ze środowiska, odpowiedzialnym za podjęcie działań zapobiegawczych i naprawczych jest solidarnie władający powierzchnią ziemi (por. art. 12 u.sz.). 
ze środowiska (art. 22). Podkreślenia wymaga fakt, że restytucja środowiska przewidziana $\mathrm{w}$ ustawie szkodowej jest zobowiązaniem sprawcy niezależnie od aktywności roszczeniowej jakichkolwiek podmiotów. Naprawienie szkody o charakterze pierwotnym spowodowanej oddziaływaniem na środowisko $\mathrm{w}$ ujęciu cywilnoprawnym ma z kolei miejsce jedynie w zakresie $\mathrm{w}$ jakim z roszczeniem wystąpi Skarb Państwa, jednostka samorządu terytorialnego, czy organizacja ekologiczna lub właściciel danego elementu środowiska.

Uzupełnieniem reżimu odpowiedzialności administracyjnej przewidzianej w ustawie szkodowej jest art. 362 ust. 1 pkt 2 u.p.o.ś., na mocy którego organ ochrony środowiska może w drodze decyzji - nałożyć na podmiot korzystający ze środowiska i negatywnie na nie oddziałujący obowiązek przywrócenia środowiska do stanu właściwego. Przepis ten stosuje się jedynie $\mathrm{w}$ takim zakresie $\mathrm{w}$ jakim nie obowiązuje ustawa szkodowa (art. 15 ust. 4). Zakładając tożsamość podmiotową sprawców w obu ustawach, różnica wynika z ograniczonej definicji szkody w środowisku w ustawie szkodowej. Wszystkie zatem przypadki negatywnego oddziaływania na środowisko, nie wyrządzające szkody w środowisku bądź zagrożenia tą szkodą według definicji ustawy o zapobieganiu szkodom w środowisku i ich naprawie, będą podlegały reżimowi art. 362 ustawy u.p.o.ś. Reżim ten jest mniej surowy - obowiązek naprawienia szkody nie powstaje bowiem ex lege, a dopiero na mocy decyzji administracyjnej, wymaga zatem w pierwszej kolejności aktywności organu administracji publicznej.

Mniej zawiłe prawnie jest naprawienie środowiskowej szkody wtórnej. Podlega ono wyłącznie jurysdykcji cywilnej na pomocy art. 144 k.c. oraz $222 \S 2$ k.c. (ochrona praw o charakterze rzeczowym), a także art. 322-327 u.p.o.ś. oraz $435 \S 1$ k.c. (delikt). W oparciu o analizę regulacji kodeksowych środowiskową szkodę wtórną można podzielić według dwóch podstawowych kryteriów, tj. po pierwsze, dobra bezpośrednio naruszonego oraz po drugie, konsekwencji tego naruszenia. Według pierwszego z nich wyróżniany szkody w majątku i w dobrach osobistych, według drugiego szkody majątkowe i niemajątko- 
we $^{31}$. Kodeksowy zakres odpowiedzialności cywilnej odnosi się jednak tylko do mienia ${ }^{32}$ (a nie całego majątku poszkodowane$\mathrm{go}^{33}$ ) lub dóbr osobistych, jako dobra bezpośrednio naruszonego (art. $435 \S 1$ k.c.; art. $444 \S 1$ k.c.; art. 448 k.c. art. $449^{2}$ k.c.). Wobec powyższego konsekwencje pierwotnej szkody środowiskowej powstające w majątku poszkodowanego (w tym jego zakresie, które nie mieści się w pojęciu mienia) - w kodeksowym ujęciu deliktu - mogą mieć jedynie charakter wtórny w stosunku do szkody na mieniu.

\section{UBEZPIECZENIA ŚRODOWISKOWE A PRAWNE UJĘCIE SZKODY I ODPOWIEDZIALNOŚCI}

Rozwój rynku ubezpieczeń środowiskowych w zakresie projektowania produktów nie może być analizowany w oderwaniu od prawnego ujęcia szkody i odszkodowania. Zarówno odpowiedzialność cywilna (administracyjna), jak i odpowiedzialność typu gwarancyjnego (której przykładem jest odpowiedzialność ubezpieczeniowa) stanowią składowe pojęcia nadrzędnego odpowiedzialności odszkodowawczej34. Współczesny charakter odpowiedzialności sprawczej jako instytucji prawnej ${ }^{35}$, a także

31 Por. Z. Radwański, A. Olejniczak, Zobowiązania - część ogólna, Warszawa 2010, s. 92.

32 Mienie - w myśl art. 44 k.c. - to własność i inne prawa majątkowe.

33 Majątek jest definiowany pozakodeksowo jako ogół wszystkich aktywów i pasywów podmiotu. Definicja taka jest założeniem, dopuszczalnym w świetle braku prawnej definicji majątku i ma zastosowanie w szczególności w kontekście umowy ubezpieczenia i definiowania przedmiotu ubezpieczenia, por. Z. Radwański, Prawo cywilne - część ogólna, Warszawa 2003, s. 135. Pamiętać jednak należy, że nauka ekonomii posługuje się tym pojęciem odmiennie. Majątkiem są aktywa, a pasywa traktowane są jako źródło finansowania majątku.

34 Por. E. Kowalewski, Ewolucja odpowiedzialności cywilnej a problem ubezpieczenia, [w:] Studia Ubezpieczeniowe IX, T. Sangowski (red.), Warszawa-Poznań 1987, s. 44.

35 Od XVII wieku podkreślano potrzebę ochrony poszkodowanego, a nie wyłącznie represję względem sprawcy, jako główny cel prawa deliktowego, por. E. Kowalewski, op.cit., s. 48. 
ekspektatywa wypłaty odszkodowania lub świadczenia nabywana wraz z zawarciem umowy ubezpieczenia posiadają podobne (o ile nie tożsame) funkcje: naprawienie szkody (rozumianej jako utrata lub zmniejszenie aktywów albo powstanie lub zwiększenie pasywów w majątku osoby poszkodowanej) lub wypłata określonego świadczenia na skutek realizacji określonego prawnie (prawna regulacja odpowiedzialności) lub umownie (umowa ubezpieczenia) wypadku ${ }^{36}$. Ubezpieczenia odpowiedzialności mają charakter akcesoryjny względem odpowiedzialności sprawczej ${ }^{37}$. W tej sytuacji mechanizm ubezpieczenia powoduje jedynie zmianę metod i technik kompensacji w istniejącej już odpowiedzialności odszkodowawczej. W pozostałych przypadkach ubezpieczenia gospodarcze wypełniają luki występujące w systemie ogólnej kompensacji cywilno-, czy administracyjnoprawnej ${ }^{38}$. Każdorazowo jednak - ze względu na tożsamość funkcji (w tym przede wszystkim kompensacyjnej) odpowiedzialności sprawczej i gwarancyjnej, uzasadnione jest założenie podobieństwa interpretacyjnego. Ponadto podnosi się, że umowa ubezpieczenia - będąc instytucją kodeksową nie może być interpretowana w oderwaniu od ogólnych zasad odszkodowania sformułowanych na gruncie prawa cywilnego ${ }^{39}$.

36 Por. W. Warkałło, Ubezpieczenia utraconych korzyści, ubezpieczenie $w$ wartości nowej $i$ ubezpieczenie $w$ wartości otaksowanej a zasada odszkodowania, [w:] Studia Ubezpieczeniowe II, J. Szpunar (red.), Warszawa-Poznań 1975, s. 51; Należy w szczególności zaznaczyć, że zadośćuczynieniu z tytułu OC przypisuje się jednak szerszą rolę niż wypłacie świadczenia z tytułu umowy ubezpieczenia. Zadośćuczynienie ma bowiem dodatkowo zapewnić pokrzywdzonemu satysfakcję moralną, poprzez obciążenie jego zapłatą sprawcy szkody. M. Wild dokonuje w tym miejscu rozróżnienia pomiędzy zadośćuczynieniem przyznawanym na mocy art. 445 § 1 k.c. (zadośćuczynienie za uszkodzenie ciała lub rozstrój zdrowia) a art. 448 (za naruszenie dobra osobistego), przypisując wskazywaną wyżej rolę jedynie temu drugiemu. Por. M. Wild, Przesłanki zadośćuczynienia pieniężnego za krzywdę związana z uszkodzeniem ciała lub uszczerbkiem na zdrowiu w praktyce sądowej, „Wiadomości Ubezpieczeniowe" 2012, wydanie specjalne, Nr 2, s. 34.

37 Por. M. Wałachowska, M. P. Ziemiak, Odszkodowanie z ubezpieczenia autocasco a VAT, „Wiadomości Ubezpieczeniowe” 2012, Nr 1, s. 54.

38 Por. W. Warkałło, op.cit., s. 76.

39 Por. W. Warkałło, op.cit., s. 47. 
Wobec powyższego, nie ulega wątpliwości, że wyżej przytoczone regulacje kodeksu cywilnego oraz szeroko rozumianego prawa środowiskowego odnośnie odpowiedzialności za szkody środowiskowe stanowią podstawę kształtowania zakresu ochrony ubezpieczeniowej. Baza ta ma charakter wystarczający dla akcesoryjnych wobec odpowiedzialności sprawczej produktów ubezpieczenia odpowiedzialności (cywilnej i administracyjnej). Nie wyczerpuje jednak swobody kontraktowej jakiej podlegają inne rodzaje ubezpieczeń. Swobodę tę dla ubezpieczeń majątkowych ograniczają artykuły $353^{1}$ oraz 821 k.c., natomiast w przypadku ubezpieczeń osobowych dodatkową barierą okazuje się wykaz grup ubezpieczeń w dziale I i II, zamieszczony w załączniku do ustawy o działalności ubezpieczeniowej ${ }^{40}$. Według wskazanych przepisów treść i cel umowy ubezpieczenia nie mogą sprzeciwiać się właściwości stosunku, ustawie i zasadom współżycia społecznego. Interes majątkowy ${ }^{41}$ - stanowiący przedmiot ubezpieczeń majątkowych - musi dodatkowo dać się ocenić $\mathrm{w}$ pieniądzu. Z kolei dopuszczalny zakres przedmiotowy ubezpieczeń osobowych nie jest zamknięty w myśl regulacji kodeksowych. Ustawodawca bowiem wskazuje, że ubezpieczenie osobowe może jedynie w szczególności dotyczyć życia, uszkodzenia ciała, czy rozstroju zdrowia (art. 829 k.c.). Doktryna akcentuje otwarty katalog przedmiotowy ubezpieczeń osobowych $^{42}$. Można je zamknąć w kategorii dóbr osobistych, które zostały w sposób również niewyczerpujący wymienione w art. 23 k.c. Problemem może się jednak okazać przyporządkowanie produktów ubezpieczenia do poszczególnych grup ubezpieczeń osobowych. Wyliczenie ustawowe ogranicza bowiem

40 Ustawa z dnia 11 września 2015 r. o działalności ubezpieczeniowej i reasekuracyjnej, Dz.U. z 2015 r. poz. 1844.

41 Przegląd definicji interesu ubezpieczeniowego, zob. m.in. A. M. Kubiak, Interes ubezpieczeniowy $w$ umowie ubezpieczenia na cudzy rachunek $i$ na rzecz osoby trzeciej, „Prawo Asekuracyjne” 2012, Nr 4, s. 69-71.

42 Otwarty katalog pozwala na innowacje produktowe i rozwój rynku ubezpieczeń. Por. B. Kęszycka, Komentarz do art. 829 kodeksu cywilnego, [w:] Prawo ubezpieczeń gospodarczych. Komentarz, Tom II, Z. Brodecki, M. Glicz, M. Serwach (red.), Lex 2010. 
ubezpieczenia osobowe do ubezpieczeń na życie, dożycie, wypadkowych i chorobowych.

Projektowanie produktu ubezpieczenia własnego (first party) wymaga zidentyfikowania możliwości rozszerzenia zakresu ochrony o sytuacje, w których prawo nie przewiduje odpowiedzialności sprawczej, a także przeanalizowania uwarunkowań, w których - ze względu na gospodarczą naturę stosunku ubezpieczenia - zakres ubezpieczenia własnego będzie węższy niż zakres prawnej odpowiedzialności sprawczej. Pierwszy obszar różnic między ubezpieczeniami własnymi a ubezpieczeniami odpowiedzialności przypisuje tym pierwszym rolę uzupełniającą w systemie naprawy szkód. Niedoskonałości i luki zasad prawnej odpowiedzialności sprawcy mogą zostać zniwelowane przez system ubezpieczeń gospodarczych. Ochrona ubezpieczeniowa pozwala bowiem realizować kompensację m.in. w sytuacji braku możliwości zidentyfikowania sprawcy, niewypłacalności sprawcy czy braku zabezpieczenia finansowego sprawcy ${ }^{43}$, a także w sytuacjach niespełnienia przesłanek prawnej odpowiedzialności za czyn powodujący szkodę ${ }^{44}$. Ponadto w ubez-

43 Brak zabezpieczenia finansowego sprawcy ma miejsce w szczególności w sytuacji nie zawarcia umowy ubezpieczenia odpowiedzialności cywilnej sprawcy. Niemniej należy mieć na uwadze również niedoskonałość akcesoryjnej wobec odpowiedzialności sprawczej odpowiedzialności ubezpieczyciela. Jest ona nierzadko dalece ograniczona postanowieniami umownym, w tym m.in. - mimo braku imperatywnego zakazu legislatora - wyłącza często winę umyślną sprawcy.

44 Brak pełności ochrony poszkodowanego może wynikać m.in. z ograniczonego zastosowania systemu odpowiedzialności na zasadzie ryzyka. Przesłanka winy w systemie odpowiedzialności na zasadzie winy pozostawia bez kompensacji szkody wobec których nie można wskazać podmiotu odpowiedzialnego, ze względu na brak winy w sprawstwie. Ponadto polski system prawa cywilnego jest uznawany za konserwatywny w zakresie pokrywania tzw. czystych strat finansowych (pure economic loss), tj. szkód finansowych niezwiązanych bezpośrednio przyczynowo z naruszeniem dóbr materialnych lub osobistych poszkodowanego (wskutek zachowania sprawcy nie dochodzi bezpośrednio do naruszenia mienia lub uszczerbku w dobrach osobistych poszkodowanego). Badania prawne wskazują, że istotnym ograniczeniem dla kompensacji tego rodzaju strat w systemie odpowiedzialności cywilnej jest art. 361 k.c. (zasada adekwatnego związku przyczynowego i normalności następstw) i na zasadzie wyjątku art. 446 k.c. (który jedynie wyjątkowo przewi- 
pieczeniach własnych nie istnieje ograniczenie w postaci umiejscowienia szkody bezpośredniej w mieniu. Kodeksowe regulacje wskazują, że przedmiotem ubezpieczenia może być każdy interes majątkowy (art. 821 k.c.), a co za tym idzie również element majątku nie stanowiący mienia ${ }^{45}$. Powyższa konstatacja wydaje się bez znaczenia dla współczesnej praktyki ubezpieczeniowej pokrywania wtórnych szkód środowiskowych, niemniej nie można wykluczyć, że umacnianie procesu poszukiwania różnych form finansowania konsekwencji realizacji ryzyka środowiskowego (także pozaubezpieczeniowych), wykształci taki element pasywów ubezpieczonego, którego poziom będzie zależał od realizacji ryzyka środowiskowego i który samoistnie będzie mógł stanowić przedmiot ubezpieczeń środowiskowych.

Podstawę ograniczenia zakresu kompensacji w ubezpieczeniach własnych będzie stanowiła natura stosunku ubezpieczenia. Jakkolwiek gospodarczy charakter umowy ubezpieczenia jest w literaturze doskonale opisany, to jednak ulega nieustannym modyfikacjom, czego konsekwencją jest stałe rozszerzanie zakresu obiektywnej ubezpieczalności ryzyka ${ }^{46}$. Trudno zatem wskazać w tym miejscu precyzyjny katalog zdarzeń, które prowadzą do ograniczenia swobody kontraktowej. Jednym z przykładów niezgodności z naturą stosunku ubezpieczenia jest występowanie elementów spekulacji w związku z kontraktami ubezpieczeniowymi. Wydaje się, że istotnie podatne na to ryzyko są ubezpieczenia osobowe w zakresie innych dóbr

duje kompensację poszkodowanego w przypadku naruszenia dóbr osobistych osoby trzeciej). Z punktu widzenia szkód środowiskowych istotne znaczenie wobec powyższego - może mieć kompensacja w systemie ubezpieczeń first party, np. w sytuacji rozlanego w morzu oleju napędowego, co spowodowało utratę zysków hoteli znajdujących się na skażonym wybrzeżu. Por. M. Mikołajewicz, Problematyka pure economic loss ze szczególnym uwzględnieniem szkody wyrządzonej przez adwokata, „Wiadomości Ubezpieczeniowe” 2010, Nr 2, s. 88-89, 95 oraz I. Kwiecień, Czyste straty finansowe - ryzyko odpowiedzialności i zakres ochrony $w$ ubezpieczeniach OC podmiotów gospodarczych. Zarys problematyki, „Wiadomości Ubezpieczeniowe” 2009, Nr 4, s. 69-70.

45 Dla przykładu szkoda może się zrealizować w pasywach podmiotu (zwiększenie pasywów) na skutek niekorzystnych zmian kursowych.

${ }^{46}$ Wraz z rozwojem nowych metod gromadzenia danych, oceny ryzyka i jego kontroli. 
osobistych niż życie i zdrowie człowieka. Nie obowiązuje bowiem w tym zakresie zasada odszkodowania, która chroni instytucję ubezpieczenia przed naruszeniem jej właściwości jedynie w zakresie majątkowych konsekwencji szkód ${ }^{47}$ oraz nie istnieje naturalna bariera psychologiczna związana $\mathrm{z}$ wewnętrzną potrzebą ochrony życia i zdrowia. W tym kontekście rodzi się pytanie o legalne (w odniesieniu do art. $353^{1}$ k.c.) podstawy chociażby dla ubezpieczenia pogorszenia jakości życia na skutek zmian stanu środowiska. Potencjalna możliwość występowania zarówno elementu spekulacji, jak również hazardu motywacyjnego ${ }^{48} \mathrm{i}$ innych elementów kontraktów, które mogą naruszać zasady obiektywnej ubezpieczalności ryzyka, wpływa (z mocy prawa i z uwzględnieniem uwarunkowań ekonomicznych) na zawężenie oferty ubezpieczeń first party w stosunku do zakresu ochrony w akcesoryjnych względem odpowiedzialności sprawczej ubezpieczeniach odpowiedzialności ${ }^{49}$.

\section{ZAKOŃCZENIE}

Problematyka ryzyka środowiskowego i ubezpieczenia środowiskowego stanowi bardzo dynamiczną grupę zagadnień ba-

47 Por. W. Warkałło, op.cit., s. 44.

48 Ciekawym zagadnieniem jest ewentualne ograniczenie swobody kontraktowej ze względu na element spekulacji czy hazardu motywacyjnego (jako atrybuty pozostające wbrew naturze stosunku ubezpieczenia) w ubezpieczeniach odpowiedzialności. Wydaje się, że ze względu na odrębność podmiotową ubezpieczonego i poszkodowanego czynniki te nie odgrywają dużego znaczenia. Konstatację tę potwierdza wyłączenie przez polskiego ustawodawcę winy umyślnej ubezpieczonego jako imperatywnej przesłanki zwolnienia ubezpieczyciela z obowiązku wypłaty odszkodowania w ubezpieczeniach odpowiedzialności (art. 827 § 2 k.c.).

49 Przykładem niech będzie wspomniane już objęcie ochroną zdarzenia polegającego na pogorszeniu jakości życia. Przy jego wątpliwej legalnej ubezpieczalności w ubezpieczeniu first party, pozostaje jednak objęte ochroną w systemie odpowiedzialności sprawczej, a co za tym idzie w systemie ubezpieczeń odpowiedzialności, które z natury rzeczy eliminują element spekulacji po stronie poszkodowanego. 
dawczych. Owa dynamika wynika z nieustannej ewolucji w zakresie identyfikacji i postrzegania zagrożeń środowiskowych zarówno na płaszczyźnie regulacji prawnych, jak i praktyki gospodarczej. Obserwowana zmienność obliguje badaczy do perspektywicznej oceny zagadnienia oraz dystansowania się wobec przeszłych koncepcji ubezpieczenia środowiskowego. Kryterium underwritingu środowiskowego, jako przedmiotowego wyróżnika ubezpieczeń środowiskowych z rynku, wydaje się odpowiadać dynamice zjawiska. Pozwala bowiem rozszerzać zakres pojęcia stosownie do zmian regulacyjnych i gospodarczych. Zdefiniowanie pojęcia szkody środowiskowej (pierwotnej i wtórnej) i przedmiotu tej szkody, w ujęciu ogólnoprawnym i ubezpieczeniowym, określenie prawnych zasad odpowiedzialności za nią jest podstawą konstruowania produktów ubezpieczeń środowiskowych, tj. produktów ubezpieczenia odpowiedzialności prawnej (third party), jak i ubezpieczeń własnych (first party) zarówno w zakresie ochrony interesów majątkowych, jak i osobowych. Precyzyjne zdefiniowanie obszaru odpowiedzialności prawnej za szkody środowiskowe jest warunkiem budowania skutecznej ochrony ubezpieczeniowej sprawców szkód, a także czynnikiem warunkującym należyte uwzględnienie interesów poszkodowanych. Nadto, respektując - w myśl postulatu zrównoważonego rozwoju - bezwzględną konieczność naprawiania tych szkód, jest podstawą finansowania tego zadania $\mathrm{z}$ uwzględnieniem zasad pełności i powszechności ubezpieczeń gospodarczych. Zakres ograniczeń odpowiedzialności sprawczej, przy uwzględnieniu natury stosunku ubezpieczenia i wykazu grup ubezpieczeń, powinien być natomiast podstawą konstrukcji produktów ubezpieczeń własnych.

Wskazane w artykule czynniki wpływające na proces projektowania produktów ubezpieczeń środowiskowych, nie wyczerpują pełnego katalogu determinant. Obok tych o charakterze prawnym, niezbędne jest branie pod uwagę faktorów ekonomicznych, czy technologicznych świadczenia usług ubezpieczenia. Powyższe przesądza o tym, że branża ubezpieczeniowa nie deklaruje chęci pokrywania samodzielnie wszystkich rodzajów ryzyka środowiskowego. Deklaracja ta dotyczy zarówno ubezpieczeń odpowiedzialności, jak i ochrony typu first party. 


\section{BIBLIOGRAFIA}

Borys G., Ryzyko ekologiczne i jego systematyka na gruncie teorii ubezpieczeniowej, [w:] Instrumenty rynkowe $w$ ochronie środowiska, S. Czaja (red.), Jugowice-Wrocław 2002.

Boyer M., Porrini D., The Efficient Liability Sharing Factor for Environmental Disasters: Lessons for Optimal Insurance Regulation, "The Geneva Papers" 2008, No. 33.

Broderick J. W., Lavoie D.R., Perel A.J., Environmental Risk Management and the Role of Environmental Insurance, "Environmental Quality Management", Autumn 2000.

Coulson A. B., Dixon R., Environmental Risk and management strategy: the implications for financial institutions, "International Journal of Bank Marketing" 1995, Vol. 13 No. 2.

Doś A., Ryzyko ekologiczne przedsiębiorstw na rynku ubezpieczeń majątkowych, Warszawa 2011.

Environmental Risks and Insurance, A Comparative Analysis of The Role of Insurance in The Management of Environment-Related Risks, "Policy Issues in Insurance" 2003, No. 6, OECD.

Fiedor B., Economic Aspects of Ecological Liability and its Insurance, International Experiences and the Polish Case, http://web.sfc.keio. ac.jp/ kgw/Research/JPJRP/ResearchPaper2003/Fiedor.pdf, 10.09.2015.

Firms may face environmental black hole, „Reactions” May 2013.

Forrest C. J., Wesley D. L., The Environmental Manager's Guide to Environmental Liability Insurance, "Environmental Quality Management" Spring 2008.

Hinteregger M., Environmental Liability and Ecological Damage in European Law, Cambridge University Press 2008.

Howard W. H., 2005 Developments in Environmental Risk Insurance, "Environmental Claims Journal", Spring 2006;

Maśniak D., Ubezpieczenia ekologiczne, Zakamycze, Kraków 2003.

Międzynarodowe prawo środowiska, wyb. i wprow. M.M. Kenig-Witkowska, Warszawa-Kraków 2009.

Minoli D. M., Bell J. N. B., Composite insurer consideration and attitudes on environmental management systems concerning public liability policies for pollution risks, "Journal of Environmental Assessment Policy and Management" 2002, vol. 4, No. 3.

Panasiewicz A., Ubezpieczenia środowiskowe jako czynnik przyspieszenia przemian prośrodowiskowych, [w:] Ubezpieczenia wobec wy- 
zwań XXI wieku, W. Ronka-Chmielowiec (red.), „Prace Naukowe Akademii Ekonomicznej we Wrocławiu" 2008, nr 1197.

Radecki W., Ustawa o zapobieganiu szkodom $w$ środowisku $i$ ich naprawie, Komentarz, Warszawa 2007.

Risk, The Environment and The Role of The Insurance Industry, UNEP Finance Initiatives, February 2003.

Rosiek K., Zakres pojęcia „szkoda ekologiczna” $w$ ubezpieczeniach ekologicznych, „Zeszyty Naukowe Akademii Ekonomicznej w Krakowie" 2006, Nr 708.

Słownik języka polskiego, t.1, Warszawa 1993.

Strzałko J., Mossor-Pietraszewska T., Kompedium wiedzy o ekologii, Warszawa-Poznań 1999.

Study on implementation effectiveness of the environmental liability directive (ELD) and related financial security issues, European Commission, Bio Intelligence Service in association with Stevens\&Bolton LLP, November 2009.

Szot M. R., Maxwell P. D., Environmental insurance gaps in coverage, "Smart Bisuness Detroit", June 2011.

Wójcik P., Ubezpieczenia odpowiedzialności za szkody w środowisku, „Prawo, Ubezpieczenia, Reasekuracja” 1998, Nr 5.

Żebrowska T., Ubezpieczenia ekologiczne a ochrona środowiska naturalnego, „Wiadomości Ubezpieczeniowe” 1997, Nr 3-4.

Kontakt e-mail:

malwina.lemkowska@ue.poznan.pl 